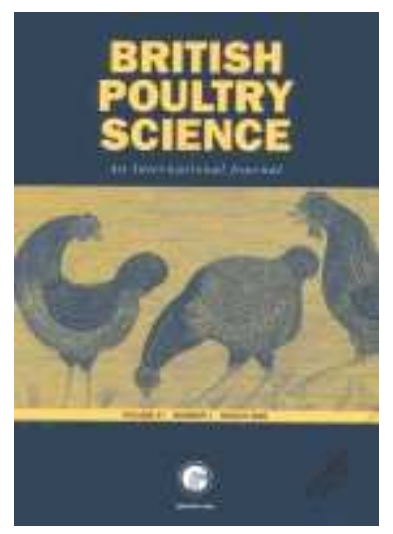

\title{
The role of loose feathers for the development of feather pecking in laying hens
}

\begin{tabular}{|r|l|}
\hline Journal: & British Poultry Science \\
\hline Manuscript ID: & CBPS-2007-193.R2 \\
\hline Manuscript Type: & Original Manuscript \\
\hline $\begin{array}{r}\text { Date Submitted by the } \\
\text { Author: }\end{array}$ & 05-Mar-2008 \\
\hline Complete List of Authors: & $\begin{array}{l}\text { von Borell, Eberhard; Martin-Luther-University Halle-Wittenberg, } \\
\text { Institute of Agricultural and Nutritional Sciences }\end{array}$ \\
\hline Keywords: & Feather pecking, Husbandry, Laying hens, Welfare \\
\hline &
\end{tabular}

\section{今 ScholarONE \\ Manuscript Central}


1 Role of loose feathers on the development of feather pecking in laying hens 2

3 S.G.A. RAMADAN AND E. VON BORELL

4

5 Institute of Agricultural and Nutritional Sciences, Faculty of Natural Sciences III,

6 Martin-Luther-University Halle-Wittenberg, Halle, Germany

7

8

9 Short title: $\quad$ Loose feathers and feather pecking

10

11

12 Correspondence to Dr Eberhard von Borell, Animal Husbandry and Ecology

13 Group, Institute of Agricultural and Nutritional Sciences, Martin-Luther-

14 University Halle-Wittenberg, Adam-Kuckhoff-Str. 35,D-06108 Halle, Germany

15 Phone: $49+345+5522332$

16 Fax: $49+345+5527106$

17 E-mail: eberhard.vonborell@1andw.uni-halle.de

18 Accepted 17 March 2008 
19 Abstract. 1. The effect of the presence of loose feathers (on the floor) on the

20 behaviour and plumage condition of laying hens (Lohmann Silver, LS) was

21 studied during the rearing and laying periods.

22 2. From 1-d-old, 60 birds in each of 4 straw-bedded pens ( $\mathrm{n}=240$ in total) with 6.5

$23 \mathrm{birds} / \mathrm{m}^{2}$ were either kept under conventional rearing and management conditions

24 (CT: control group with feathers on the floor; $n=120)$ or in pens from which the

25 feathers were collected from the floor 4 times/week (FR: feathers removed;

$26 \mathrm{n}=120)$. Fifty birds from each of these 4 groups $(\mathrm{n}=200$ in total) were randomly

27 selected at the age of 16 weeks and allocated to 4 identical pens in a poultry layer

28 house ( $\mathrm{PH}$; with perches and $1 / 3$ slatted floor) with access to an outside area

29 (winter garden, WG) at a stocking density of 6 birds $/ \mathrm{m}^{2}$ in both $\mathrm{PH}$ and WG.

30 3. Observations on feather pecking and other behaviours (feeding, drinking,

31 preening, standing, sitting, foraging, moving and dust bathing) were carried out at

328 ages: $6,10,15$ (rearing period), 20, 25, 30, 35 and 40 weeks (laying period).

33 Feather scoring was carried out at 15, 32 and 39 weeks of age.

34 4. There were no differences in feather pecking rates, forms (gentle, severe and

35 aggressive pecks) as well as in the plumage condition between groups at the end

36 of the rearing period.

37 5. Birds in the FR group exhibited lower rates and less severe feather pecking 38 during the laying period. Accordingly, birds in the control group had worse 39 feather condition at 32 and 39 weeks of age. Feather pecking rates within groups 40 were, in general, greater in the afternoon compared to the morning periods. Birds 41 in the control group were more active in walking. 
42 6. Wings, rump, tail and back were the main targets for feather pecking. The

43 majority of feather pecking occurred on the floor (66\%) followed by feeding area $44(26 \%)$, perches $(4 \%)$ and slats $(4 \%)$.

45 7. Our results suggest that loose feathers on the floor may play an important role 46 in the development and severity of feather pecking behaviour in laying hens and

47 support the hypothesis (McKeegan and Savory 1999) that feather pecking can be 48 viewed as redirected foraging behaviour.

\section{INTRODUCTION}

51 Feather pecking is interpreted as an abnormal behaviour where laying hens peck

52 the feathers of conspecifics, damage the plumage or even injure the skin. It is

53 considered as one of the most widespread and serious problems of today's poultry

54 production when hens are kept under commercial conditions (Savory, 1995;

55 Blokhuis et al., 2000). It reduces welfare in the recipient birds, because it has been

56 suggested that having feathers pulled out is perceived as painful (Gentle and

57 Hunter, 1990) and can lead to cannibalism (Allen and Perry, 1975). Moreover, it

58 increases economical losses due to increased mortality, reduction in egg

59 production (El-Lethy et al., 2000), increased food consumption (Leeson and

60 Morrison, 1978), and is also associated with increased (chronic) fear (Hughes and

61 Duncan, 1972; Ouart and Adams, 1982). Johnsen et al. (1998) emphasised the

62 importance of early rearing conditions (litter substrate) on the development of

63 feather pecking behaviour, of which the presence of loose feathers on the floor in

64 early life may affect subsequent pecking behaviour. Feather eating has been

65 observed in commercial layers (Savory and Mann, 1997; Harlander-Matauschek 
66 and Bessei, 2005). Pullets prefer to eat shorter semiplumes $(<10 \mathrm{~cm})$ rather than

67 longer ones, and once feather eating has become established, a shortage of loose

68 feathers on pen floors may cause a redirected pecking and eating of feathers from

69 other birds (McKeegan and Savory, 1999). Similarly, Forkman (2003) reported

70 that feather pecking can be viewed as foraging behaviour in which the birds first

71 learn to peck at loose feathers on the floor and then develop into proper feather

72 pecking when there are no more feathers available. The objective of this study

73 was to investigate the effect of feather presence or absence on the floor on various

74 behaviours of LS laying hens with emphasis on feather pecking and plumage

75 condition.

\section{MATERIALS AND METHODS}

\section{Birds and housing condition}

79 A total of 240 1-d-old layer hen chicks (Lohmann Silver, LS) were either kept in 80 two pens under conventional rearing and management conditions (CT; $n=2 \times 60$ )

81 or in two pens from which the feathers were collected from the floor 4 times/week

82 (FR; $n=2 \times 60)$. Fifty birds from each of these 4 groups $(n=200$ in total) were

83 randomly selected at the age of 16 weeks and allocated to 4 identical pens in a

84 poultry layer house ( $\mathrm{PH}$; with perches and 1/3 slatted floor, the remaining part 85 was deep litter area with straw) with unrestricted access to an outside area (winter 86 garden, WG, littered with shredded tree bark) at a stocking density of $6 \mathrm{birds} / \mathrm{m}^{2}$

87 in both $\mathrm{PH}$ and WG. All selected hens remained in their original rearing group.

88 The treatment in the laying period (presence or absence of feathers on the floor in

89 the $\mathrm{PH}$ and $\mathrm{WG}$ ) was the same for all birds as in the rearing period. Each group 
90 had access to 4 nests $(60 \mathrm{~cm} \times 30 \mathrm{~cm} \times 30 \mathrm{~cm})$. Four perches were placed $50 \mathrm{~cm}$

91 above the slats which allowed $15 \mathrm{~cm}$ space on the perch for each bird. Two round

92 feeders were fixed $20 \mathrm{~cm}$ above the floor and 5 nipple drinkers under the perches

93 allowed access to one nipple for 10 hens according to the EU-Council Directive

94 (1999/74/EC). Food and water were provided ad libitum. The light regimen in the

95 house was $14 \mathrm{~h}$ light: $10 \mathrm{~h}$ dark with a light intensity of 4-6 lux and temperatures

96 indoors were kept between $11^{\circ} \mathrm{C}$ and $28^{\circ} \mathrm{C}$.

\section{Procedures}

\section{Behavioural observations}

99 Hens of each pen group were directly observed in two 3-h periods, once in the 100 morning (9.00-12.00 h) and the second in the afternoon (13.00-16.00 h). Each 101 group was directly observed for $15 \mathrm{~min}$ in each observation period by a person

102 who was sitting outside the pen on a high chair with a good view over the whole

103 pen. Because it was impossible to observe the entire pen at one time, each pen 104 was subdivided into two equal segments (Sanotra et al., 2002) that were observed 105 separately. The birds were accustomed to the presence of the observer for $5 \mathrm{~min}$ 106 before initiation of behavioural recording.

107 Feather pecking

108 All occurrences (Altmann, 1974) of feather pecking interactions in a group were 109 recorded (5 periods of $3 \mathrm{~min}$ ). Feather pecks that were successively directed at the 110 same receiver were recorded as one single interaction. An interaction ended when 111 there were no more pecks during a period of $4 \mathrm{~s}$. Interactions were classified as: 112 A-“Gentle”: gentle pecks at feathers, not resulting in feathers being pulled out 113 and neither does the receiver show a reaction to the peck. B-"Severe": forceful 
114 pecks, sometimes feathers are pulled out and the receiver of the peck may move

115 away. C-“Aggressive”: were always severe and fast, directed mainly at the head

116 and given in a downward direction, occasionally when the attacked bird was

117 moving away; an aggressive peck could also be directed to other parts of the

118 body. The body parts to which pecks were directed (head, neck, back, rump, tail,

119 wing, belly, breast and leg) were recorded. All rates of feather pecking are given

120 as number of occurrences.

121 Other behavioural activities

122 The recording of feather pecking interactions was briefly interrupted every 3 min

123 for a scan sample of other activities. The number of birds engaged in 8 mutually-

124 exclusive activities were recorded for each scan (feeding, drinking, preening,

125 standing, sitting, foraging, moving and dust bathing). The percentage of birds

126 engaged in each behaviour was calculated during all scan samples for each pen.

127 Behavioural observations were carried out at 8 ages: 6, 10, 15 (rearing period), 128 and 20, 25, 30, 35 and 40 weeks (laying period in PH and WG). In addition, the

129 location (perch, floor, slats and feeding area) of the recipient bird during feather 130 pecking was recorded.

$131 \quad$ Feather scoring

132 All birds from each pen were individually scored at 15, 32 and 39 weeks of age.

133 For inspection of feather condition, each bird was taken from the pen and 11

134 individual parts of the body (Gunnarson et al., 1995), "head, neck, under the neck, 135 back, rump, tail, wings (wing-primary feathers and wing coverts), abdomen, 136 breast and legs" were carefully examined for damaged, broken, and missing 137 feathers and bald patches. Each body part was given a score from 0 (best) to 6 
138 (worst), with special criteria used for scoring of flight feathers (the tail and the

139 primaries) compared to the feathers of the rest of the body that were differentiated

140 for the types, number, length and damages (Table 1). The feathers under the neck

141 and breast were excluded because of the interfering effects of feeder edge and

142 brood patch on feather damage. A sum of all given values was taken as a total

143 body score.

144 (INSERT TABLE 1).

145 Statistical analysis

146 Data from behavioural observations, the number of feather pecking in different

147 areas and locations as well as feather scores at different parts of the body were

148 analysed using generalised linear models (T-test: GLM- procedure, SAS Institute,

149 2001). Behavioural observations data from different ages were combined for the

150 analysis within the rearing and laying period. Residuals were tested for normal

151 distribution before analysis.

152 The following model was used:

$153 \quad Y_{i k l}=G_{i}+P_{e} r_{k}+\operatorname{residual}_{i k l}$

154 where

$155 Y=$ feather pecking or the type of behaviour observed (feeding, drinking,

156 foraging, preening, walking, standing and dust bathing), Feather score

$157 \quad G_{i}=$ effect of group (feather treatment)

$158 \quad \mathrm{Per}_{k}=$ effect of period $(\mathrm{k}=$ morning or afternoon $)$

$159 \quad$ Residual $=$ residual factors. 


\section{RESULTS}

161 There were no differences in the rates of feather pecking, as well as feather

162 pecking forms (gentle, severe and aggressive pecks) between the CT and FR

163 groups in the rearing period, as shown in Table 2. In contrast, birds in the CT 164 groups exhibited a higher rate of feather pecking $(P=0.007$; see Table 3$)$, and a 165 more severe form of this behaviour $(P<0.001)$ in the laying period. Hens in the FR 166 group exhibited more gentle FP $(P<0.05$; see Figure 1).

167 (INSERT TABLES 2 and 3 and FIGURE 1)

168 Time of day had an effect on the rate of feather pecking, as feather pecking 169 rates within the groups were in general greater in the afternoon compared to the 170 morning periods $(P<0.001, \mathrm{CT} ;<0.05$, FR $)$. However, the control group 171 exhibited higher rates of afternoon feather pecking compared to the FR group $172(P=0.011$; see Table 3).

173 The distribution of feather pecking to the various body regions are shown 174 in Figures $2 \mathrm{a}$ and $2 \mathrm{~b}$. Birds in the control group pecked to a greater extent to most 175 of the body parts in both the $\mathrm{PH}$ and $\mathrm{WG}$, however, the difference did not reach 176 significance. Wings, rump, tail and back were the main targets for feather 177 pecking.

178 (INSERT FIGURES 2a, b)

179 Behavioural activities were similar for both groups except for walking (see 180 Table 4). The percentage of hens walking was greater $(P=0.004)$ in birds of the 181 control group.

(INSERT TABLE 4) 
Feather condition of the different body regions as well as the sum of total

184 feather score was similar between groups during the rearing period $(P>0.05)$. In

185 general there was little plumage deterioration at the end of the rearing period.

186 Results from feather scoring at different ages during the laying period are shown

187 in Table 5.

$188 \quad$ (INSERT TABLE 5)

189 Plumage damage increased with age during the laying period. At 32 weeks

190 of the age, feather condition on the back and wing-coverts of the birds in the CT

191 groups were worse than for the FR birds ( $\mathrm{p}=0.043,0.007$, respectively).

192 Accordingly, birds in the FR group had less damaged feathers on the neck, back,

193 wing-coverts and leg $(P=0.019,0.044,0.029,0.001$, respectively $)$ at 39 weeks of

194 the age. In addition, the sum of feather scores for all body parts was better in

195 birds of the FR groups at 32 and 39 weeks of age $(P=0.002,0.007$, respectively).

In Figure 3 feather pecking (\%) is compared at

197 different locations. Most feather pecking occurred on the floor, followed by the

198 feeding area, slats and perches in both groups.

199 (INSERT FIGURE 3)

200

201

\section{DISCUSSION}

202 The hypothesis that feather eating may be a precursor to subsequent damaging 203 pecks (Savory and Mann, 1997; McKeegan and Savory, 1999) is supported by our 204 results, which suggested that birds may have learnt to peck and to eat loose 205 feathers from the floor that were available during the rearing period, because 206 feather moulting occurs three times during this period (Appleby et al., 1992). 
207 When there is a shortage of loose feathers during the laying period, attention may

208 have been redirected towards the feathers of conspecifics and hence developed

209 into feather pecking. This is indicated by an increase in both total rate and severity

210 of feather pecking in the control group. Although highly significant, these

211 treatment differences were relatively small. Nevertheless, this result tends to be

212 consistent with McKeegan and Savory (1999), who reported that short feathers

213 were eaten preferentially and long feathers were partially eaten by pullets when

214 short feathers were no longer available from the litter; once feather eating has

215 become established, a low availability of suitable-sized feathers may cause feather

216 eating and pecking to be redirected towards other birds. Also, Forkman (2003)

217 found that birds that had previously loose feathers on the floor (during the rearing

218 period) displayed a more severe feather pecks at 20 weeks of age than those

219 deprived of loose feathers. Unfortunately his experiment was terminated after

220 three days of observations due to ethical reasons.

221 Feather pecking was observed with a higher frequency in the afternoon, in

222 accordance with a study of Preston (1987) who found feather pecking in general

223 to occur mostly in the afternoon. Birds showed increased activities in the

224 afternoon with more foraging, dust bathing, movement and feeding (Vestergaard,

225 1982; Appleby et al., 1992; Channing et al., 2001), which might be accompanied

226 by more feather pecking. This supports our results which showed that increased

227 walking activity was accompanied with a higher rate of feather pecking in the

228 control groups. Also, our results are in agreement with Newberry et al. (1988) and

229 Riber et al. (2007) who reported that an increase in general activity leads to

230 increases in feather pecking behaviour. Klein et al. (2000) reported that increased 
231 moving is a sign of frustration. It can be interpreted as an attempt to increase the

232 chances of finding the stimuli which the birds need. Mahboub et al. $(2002,2004)$

233 found that walking and the frequency of short outdoor visits in free range laying

234 hens was associated with a high probability of occurrence for being pecked.

235 Hens located on the floor were reported to receive more feather pecks than

236 hens on the perches (Wechsler and Huber-Eicher, 1998). This supports our results

237 that the majority of feather pecks occurred on the floor during the laying period.

238 This may be attributed to many behaviours performed on the floor such as sitting

239 or standing on the floor, and dust bathing behaviour which were found to be

240 associated with a high frequency of feather pecking (Vestergaard, 1994; Huber-

241 Eicher and Wechsler, 1998). In addition, Bilčik and Keeling (2000) reported

242 increasing frequency of aggressive pecks with increasing group size.

243 Most feather pecks in the current study were directed to the wings, rump,

244 tail and back, in agreement with findings from other studies (for example,

245 Wechsler et al., 1998). Savory and Mann (1999) reported that feather loss

246 typically commenced at the base of the back where litter particles tend to be

247 attached and where there are relatively short feathers, which may be both easily

248 plucked and preferred for eating.

249 Feather scoring is often used as a convenient measure to assess feather 250 pecking in flocks of laying hens (Hughes and Duncan, 1972; Gunnarsson et al., 251 1999). Our results demonstrated that there was little plumage deterioration at the 252 end of the rearing period. This may be attributed to a low rate of the severe form 253 of feather pecking observed in the current study during the rearing period which 254 usually causes most of the feather damage. Proctor and Lynch (1993) reported 
255 that relatively minimal feather pecking combined with a rapid series of moults 256 during the first months of life may explain why pullets reared commercially often

257 appear to be fully feathered, however, feather pecking does take place during the 258 rearing period. Plumage deterioration increased with age during the laying period.

259 A rise in the rate of feather pecking has been found to correspond with the rise in 260 gonadal hormones inducing egg laying (Hughes, 1982). Rodenburg and Koene 261 (2003) also reported that the intensity and severity of feather pecking seems to 262 depend on age. Gentle feather pecking is mostly observed in young chickens 263 (Kjaer and Sørensen, 1997; Wechsler et al. 1998) and severe feather pecking is 264 more often seen at a later age (Huber-Eicher and Sebö, 2001b). This may explain 265 the rapid changes in plumage condition of different body parts that were recorded 266 during the laying period. Hens in the control groups were rated with a worse 267 feather score than hens in the FR groups. This may be attributed to the difference 268 in the amount and severity of feather pecking behaviour among groups, which 269 was reflected in the plumage condition. Because birds in the control groups have 270 learnt to peck and eat feathers from the floor, and due to a lack of feathers from 271 the floor during the laying period, they have pecked, pulled out and eaten feathers 272 from pen mates. Therefore, feather pecking rates as well as the severe form of this 273 behaviour were highest in the control groups leading to a deterioration of feathers. 274 This is in agreement with Huber-Eicher and Sebö $(2001 a, b)$ who found that 275 individuals characterised by relatively high rates of feather pecking performed 276 more frequently the severe form of this behaviour. Also, Huber-Eicher and Sebö 277 (2001a) reported that feather scoring actually measures indirectly the amount of 
278 severe feather pecks, but because of the proportionality it also indicates the total 279 amount of feather pecking.

280 The suggestion that feather damage is caused by severe feather pecks is 281 supported by the results from Vestergaard et al. (1993) and Bilčik and Keeling 282 (1999) who demonstrated that severe feather pecks and not gentle feather pecks or 283 aggressive pecks caused most of the feather damage on the body of the laying 284 hens. Moreover, McAdie and Keeling (2000) found that damaged or broken 285 feathers or even denuded areas due to feather loss may stimulate more feather 286 pecking.

287 In conclusion, our results suggest that the presence of loose feathers on the 288 floor may play an important role in the development and severity of feather 289 pecking behaviour in laying hens, and support the hypothesis that feather pecking 290 can be viewed as redirected foraging behaviour. However, these results need to be 291 verified on the basis of larger sample and group sizes.

\section{REFERENCES}

294 ALLEN, J. \& PERRY, G.C. (1975) Feather pecking and cannibalism in a caged 295 layer flock. British Poultry Science, 16: 441-451.

ALTMANN, J. (1974) Observational study of behaviour: sampling methods. Behaviour, 49: 227-267.

298 APPLEBY, M.C., HUGHES, B.O. \& ELSON, A.H. (1992) Poultry Production 299 Systems: Behaviour, Management and Welfare. CAB_International, $300 \quad$ Wallingford, UK. 
301 BILČIK, B. \& KEELING, L.J. (1999) Changes in feather condition in relation to feather pecking and aggressive behaviour in laying hens. British Poultry Science, 40: 444-451.

BILČIK, B, \& KEELING L.J. (2000) Relationship between feather pecking and ground pecking in laying hens and the effect of group size. Applied Animal Behaviour Science, 68: 55-66.

BLOKHUIS, H.J., EKKEL, E.D., KORTE, S.M., HOPSTER, H. \& REENEN, van C.G. (2000) Farm animal welfare research in interaction with society. Veterinary Quarterly, 22: 17- 22.

CHANNING, C.E., HUGHES, B.O. \& WALKER, A.W. (2001) Spatial distribution and behaviour of laying hens housed in an alternative system. Applied Animal Behaviour Science, 72: 335-345.

COUNCIL DIRECTIVE (EC) No. 74/1999 laying down minimum standards for the protection of laying hens. L203: 53-57.

EL-LETHY, H., AERNI, V., JUNGI, T.W. \& WECHSLER, B. (2000) Stress and feather pecking in laying hens in relation to housing conditions. British Poultry Science, 41: 22-28.

FORKMAN, B.A. (2003) Feather pecking and feather eating in laying hens. Proceedings of the $37^{\text {th }}$ International Congress of the ISAE, Abano Terme, Italy, p. 61 .

GENTLE, M.J. \& HUNTER LN. (1990) Physiological and behavioural responses associated with feather removal in Gallus gallus var domesticus. Research in Veterinary Science, 27: 149-157. 
324 GUNNARSSON, S., ODEN, K., ALGRES, B., SYEDBERG, J. \& KEELING, L.J. (1995) Poultry health and behaviour in a tiered system for loose housed layers. Report 35, Swedish University of Agricultural Sciences, Department of Animal Hygiene, Skåra, Sweden.

328 GUNNARSSON, S., KEELING, L.J. \& SYEDBERG, J. (1999) Effect of rearing 329 factors on the prevalence of floor eggs, cloacal cannibalism and feather 330 pecking in commercial flocks of loose housed laying hens. British Poultry $331 \quad$ Science, $40: 12-18$.

332 HARLANDER-MATAUSCHEK, A. \& BESSEI, W. (2005) The effect of feather 333 eating and crop filling in laying hens. Archiv für Geflügelkunde 69: 241334244.

335 HUBER-EICHER, B. \& SEBÖ, F. (2001a) Reducing feather pecking when 336 raising laying hen chicks in aviary systems. Applied Animal Behaviour $337 \quad$ Science, $73:$ 59-68.

338 HUBER-EICHER, B \& SEBÖ, F. (2001b) The prevalence of feather pecking and 339 development in commercial flocks of laying hens. Applied Animal $340 \quad$ Behaviour Science, 74: 223-231.

341 HUBER-EICHER, B. \& WECHSLER, B. (1998) The effect of quality and 342 availability of foraging materials on feather pecking in laying hen chicks. 343 Animal Behaviour, 55: 861-873.

344 HUGHES, B.O (1982). Feather pecking and cannibalism in domestic fowls, in: 345 BESSEI, W., (Ed), Disturbed Behaviour in Farm Animals, pp. 138-146 346 (Verlag Eugen Ulmer, Stuttgart, Germany). 
347 HUGHES, B.O. \& DUNCAN. I.J.H. (1972) The influence of strain and 348 environmental factors upon feather pecking and cannibalism in fowls. $349 \quad$ British Poultry Science, 13: 525-547.

350 JOHNSEN, P.F., VESTERGAARD, K.S. \& NORGAARD-NIELSEN, G. (1998)

351 Influence of early rearing conditions on the development of feather pecking 352 and cannibalism in domestic fowl. Applied Animal Behaviour Science, 60: $353 \quad 25-41$

354 KJAER, J.B. \& SØRENSEN P. (1997) Feather pecking in White leghorn chickens-a genetic study. British Poultry Science, 38: 333-341.

356 KLEIN, T., ZELTNER. E. \& HUBER-EICHER, B. (2000) Are genetic 357 differences in foraging behaviour of laying hen chicks paralleled by hybrid358 specific differences in feather pecking? Applied Animal Behaviour Science, 70: $143-155$.

LEESON, S. \& MORRISON, W.D. (1978) Effect of feather cover on feed efficiency in laying birds. Poultry Science, 57: 1094-1096.

362 MAHBOUB, H.D.H., von BORELL, E. \& MÜLLER, J. (2002) Feather pecking in laying hens with free access to outdoor enclosures. Proceedings of the 11th European Poultry Conference, Sept 6-10; Bremen, Germany, p. 79.

MAHBOUB, H.D.H., MÜLLER, J. \& von BORELL, E. (2004) Locomotion, tonic immobility, heterophil/lymphocyte ratio and feather condition in free

368 McADIE, T.M. \& KEELING, L.J. (2000) Effect of manipulating feathers of 369 laying hens on the incidence of feather pecking and cannibalism. Applied Animal Behaviour Science, 68: 215-29. 
371 McKEEGAN, D.E.F. \& SAVORY, C.J. (1999) Feather eating in layer pullets and 372 its possible role in the aetiology of feather pecking damage. Applied Animal

374 NEWBERRY, R.C., HUNT, J.R. \& GARDINER, E.E. (1988) Influence of light

PROCTOR, N.S. \& LYNCH, P.J. (1993) Manual of Ornithology, Avian Structure and Function. Yale University Press, New Haven, USA.

RIBER, A.B., WICHMAN, A., BRAASTAD, B.O. \& FORKMAN, B. (2007) pecking by caged layers. British Poultry Science, 28: 653-658.

OUART, M.D. \& ADAMS, A.W. (1982) Effects of cage design and bird density on layers. 1. Productivity, fearfulness, and nervousness. Poultry Science, 61: 1606-1613. 
394 SAVORY, C.J. (1995) Feather pecking and cannibalism. World's Poultry Science 395 Journal, 51: 215-219.

SAVORY, C.J. \& MANN, J.S. (1997) Behavioural development in groups of pen housed pullets in relation to genetic strain, age and food form. British Poultry Science, 38: 38-47.

SAVORY, C.J. \& MANN, J.S. (1999) Feather pecking in groups of growing bantams in relation to floor litter substrate and plumage colour. British Poultry Science, 40: 565-572.

VESTERGAARD, K.S. (1982) Dustbathing in the domestic fowl-diurnal rhythm and dust deprivation. Applied Animal Ethology, 8: 487-495.

404 VESTERGAARD, K.S. (1994) Dustbathing and its relation to feather pecking in the fowl: motivational and developmental aspects. PhD Thesis. The Royal Veterinary and Agricultural University, Dept. of Animal Science and Animal Health, Copenhagen, Denmark.

VESTERGAARD, K.S. KRUIJT, J.P. \& HOGAN, J.A. (1993) Feather pecking and chronic fear in groups of red junglefowl: their relations to dustbathing, rearing environment and social status. Animal Behaviour, 45: 1127-1140.

WECHSLER, B. \& HUBER-EICHER, B. (1998) The effect of foraging material and perch height on feather pecking and feather damage in laying hens. Applied Animal Behaviour Science, 58: 131-141.

414 WECHSLER, B., HUBER-EICHER, B. \& NASH, D.R. (1998) Feather pecking in 415 growers: a study with individually marked birds. British Poultry Science, $416 \quad 39: 178-185$. 
417 TABLE 1. Description of the scoring method used to evaluate feather condition

418 (modified from previous methods, BILČIK and KEELING 1999). A different scale

419 was used for flight feathers (wing primaries and tail) compared to feather

420 condition of the rest of the body

\begin{tabular}{|c|c|c|}
\hline Scores & Body feather & Flight feather \\
\hline 0 & Intact feathers. & Intact feathers. \\
\hline 1 & $\begin{array}{l}\text { Some feathers scruffy and/or } \\
\text { up to } 5 \text { damaged feathers. }\end{array}$ & $\begin{array}{l}\text { Few separated feathers up to } 5 \text {, } \\
\text { but none damaged, broken or } \\
\text { missing. }\end{array}$ \\
\hline 2 & $\begin{array}{l}>5 \text { damaged feathers and/or } \\
\text { up to } 5 \text { broken feathers. }\end{array}$ & $\begin{array}{l}>5 \text { feathers separated and/or up } \\
\text { to } 5 \text { damaged feathers. }\end{array}$ \\
\hline 3 & $\begin{array}{l}>5 \text { broken feathers and/or } \\
\text { up to } 5 \text { missing feathers. }\end{array}$ & $\begin{array}{l}\text { All feathers separated, or }>5 \\
\text { feathers damaged or up to } 3 \\
\text { broken. }\end{array}$ \\
\hline 4 & Bald patch $<50 \%$ of area. & $\begin{array}{l}\text { All feathers damaged and/or }>3 \\
\text { feathers broken or up to } 3 \\
\text { feathers missing. }\end{array}$ \\
\hline 5 & Bald patch $>50 \%$ of area. & $\begin{array}{l}\text { All feathers broken or }>3 \\
\text { feathers missing. }\end{array}$ \\
\hline 6 & Completely denuded area. & Almost all feathers missing. \\
\hline
\end{tabular}


421 TABLE 2. Least squares means ( \pm standard error) and P-value for feather

422 pecking (FP) rate and feather pecking forms during the rearing period

\begin{tabular}{lccc}
\hline Items & Control & Feather Removal & $P$-value \\
\hline Total FP (n) & $9.77( \pm 1.13)$ & $8.53( \pm 0.76)$ & $\mathrm{NS}$ \\
Gentle FP & $6.50( \pm 1.07)$ & $5.70( \pm 0.72)$ & $\mathrm{NS}$ \\
Severe FP & $2.63( \pm 0.39)$ & $2.27( \pm 0.32)$ & $\mathrm{NS}$ \\
Aggressive FP & $0.63( \pm 0.11)$ & $0.57( \pm 2.11)$ & $\mathrm{NS}$ \\
\hline
\end{tabular}


423 TABLE 3. Least squares means ( \pm standard error) and P-value for feather

424 pecking rate and effect of day time (laying period)

\begin{tabular}{|c|c|c|c|}
\hline Items & Control & Feather removal & $I$-value \\
\hline Total feather pecking & $12.60^{\mathrm{a}}( \pm 0.53)$ & $11.01^{\mathrm{b}}( \pm 0.40)$ & 0.007 \\
\hline \multicolumn{4}{|l|}{ Time of day } \\
\hline $\mathrm{am}$ & $11.22( \pm 0.56)$ & $10.16( \pm 0.44)$ & NS \\
\hline $\mathrm{pm}$ & $13.98 * * *( \pm 0.86)$ & $11.86 *( \pm 0.65)$ & 0.011 \\
\hline
\end{tabular}

425 Statistically significant at $* P<0.05, * * * P<0.001$ (within the group). 
426 TABLE 4. Least squares means ( \pm standard error) and P-value for total number of hens (\%) observed performing various behaviours

\begin{tabular}{lccc}
\hline Behaviour & Control & Feather removal & $P$-value \\
\hline Feeding & $10.84( \pm 1.18)$ & $11.87( \pm 1.35)$ & NS \\
Drinking & $8.11( \pm 0.92)$ & $7.99( \pm 0.89)$ & $\mathrm{NS}$ \\
Foraging & $30.93( \pm 1.89)$ & $32.86(1.83)$ & $\mathrm{NS}$ \\
Preening & $16.50( \pm 1.09)$ & $14.07( \pm 0.88)$ & $\mathrm{NS}$ \\
Walking & $8.39^{\mathrm{a}}( \pm 0.39)$ & $6.13^{\mathrm{b}}( \pm 0.50)$ & 0.004 \\
Standing & $10.71( \pm 1.00)$ & $10.47( \pm 0.78)$ & $\mathrm{NS}$ \\
Sitting & $7.51( \pm 0.56)$ & $7.69( \pm 0.72)$ & $\mathrm{NS}$ \\
Dustbathing & $3.94( \pm 0.90)$ & $5.93( \pm 0.98)$ & $\mathrm{NS}$ \\
\hline
\end{tabular}


428 TABLE 5. Least squares means ( \pm standard error) and $P$-value for feather scoring at 32 and 39 weeks of age

\begin{tabular}{|c|c|c|c|c|c|c|}
\hline Items & Control & $\begin{array}{l}\text { Feather } \\
\text { removal }\end{array}$ & $P$-value & Control & $\begin{array}{l}\text { Feather } \\
\text { removal }\end{array}$ & $P$-value \\
\hline Body parts & 32 weeks & & & 39 weeks & & \\
\hline Head & $1.84( \pm 0.08)$ & $1.76( \pm 0.06)$ & NS & $2.71( \pm 0.10)$ & $2.68( \pm 0.12)$ & NS \\
\hline Neck & $2.50( \pm 0.07)$ & $2.41( \pm 0.07)$ & NS & $3.84^{\mathrm{a}}( \pm 0.06)$ & $3.62^{\mathrm{b}}( \pm 0.08)$ & 0.019 \\
\hline Back & $1.88^{\mathrm{a}}( \pm 0.05)$ & $1.73^{b}( \pm 0.07)$ & 0.043 & $3.04^{\mathrm{a}}( \pm 0.11)$ & $2.74^{\mathrm{b}}( \pm 0.10)$ & 0.044 \\
\hline Rump & $1.74( \pm 0.09)$ & $1.53( \pm 0.07)$ & NS & $2.51( \pm 0.08)$ & $2.66( \pm 0.09)$ & NS \\
\hline Tail & $2.54( \pm 0.07)$ & $2.41( \pm 0.09)$ & NS & $2.71( \pm 0.09)$ & $2.55( \pm 0.08)$ & NS \\
\hline Wing-coverts & $2.02^{\mathrm{a}}( \pm 0.05)$ & $1.73^{b}( \pm 0.09)$ & 0.007 & $2.96^{\mathrm{a}}( \pm 0.06)$ & $2.72^{\mathrm{b}}( \pm 0.07)$ & 0.029 \\
\hline Wing primaries & $3.18( \pm 0.07)$ & $3.10( \pm 0.07)$ & NS & $3.38( \pm 0.05)$ & $3.68( \pm 0.08)$ & NS \\
\hline Belly & $1.26( \pm 0.07)$ & $1.12( \pm 0.04)$ & NS & $2.45( \pm 0.08)$ & $2.36( \pm 0.08)$ & NS \\
\hline Leg & $2.22( \pm 0.06)$ & $2.22( \pm 0.06)$ & NS & $3.78^{\mathrm{a}}( \pm 0.06)$ & $3.40^{\mathrm{b}}( \pm 0.10)$ & 0.001 \\
\hline Total body parts & $19.18^{\mathrm{a}}( \pm 0.24)$ & $18.02^{\mathrm{b}}( \pm 0.28)$ & 0.002 & $27.84^{\mathrm{a}}( \pm 0.34)$ & $26.43^{\mathrm{b}}( \pm 0.45)$ & 0.007 \\
\hline
\end{tabular}




\section{Feather pecking}

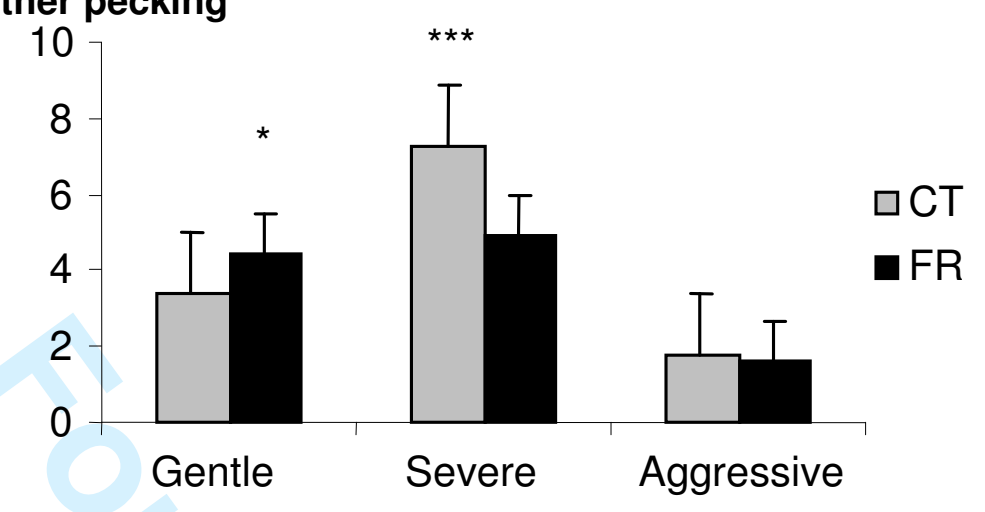

443 during the laying period $(* * * P<0.001, * P<0.05)$. 
444

445

446

447

448

449

450

451

452

453

454

455

456

457

458

459

460

461

462

463

464

465

466

467

468

469

470

471

472

473

474

a. Poultry house

\section{Feather pecking}

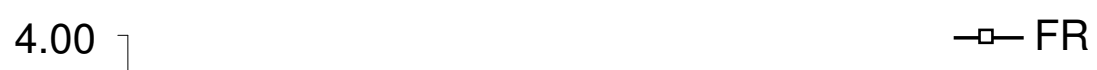

3.00

2.00

1.00

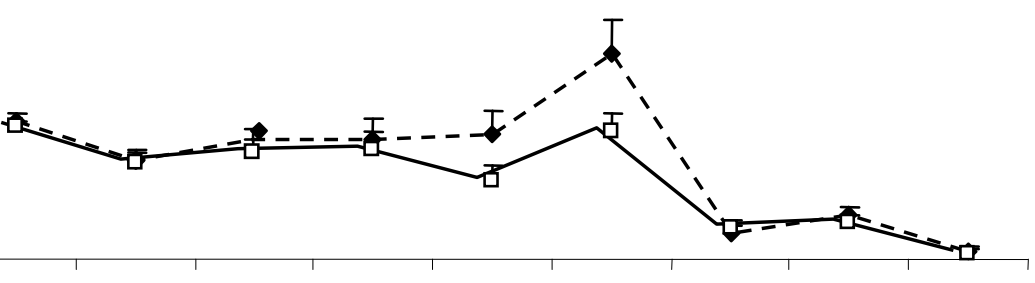

Head Neck Back Rump Tail Wing Belly Leg Breast Body region

b. Winter garden

\section{Feather pecking}

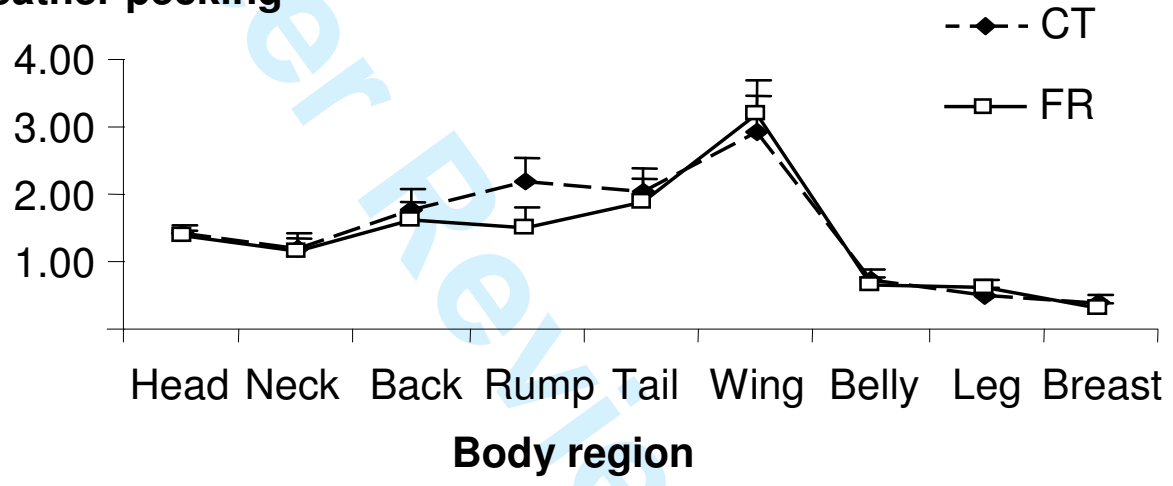

FIGURE 2. Least squares means ( \pm standard error) for the feather pecking directed to various body parts in the Poultry house (a) and Winter garden (b). 
475

476

477

478

479

480

481

482

483

484

485

486

487

488

489

$\%$ of Feather pecking

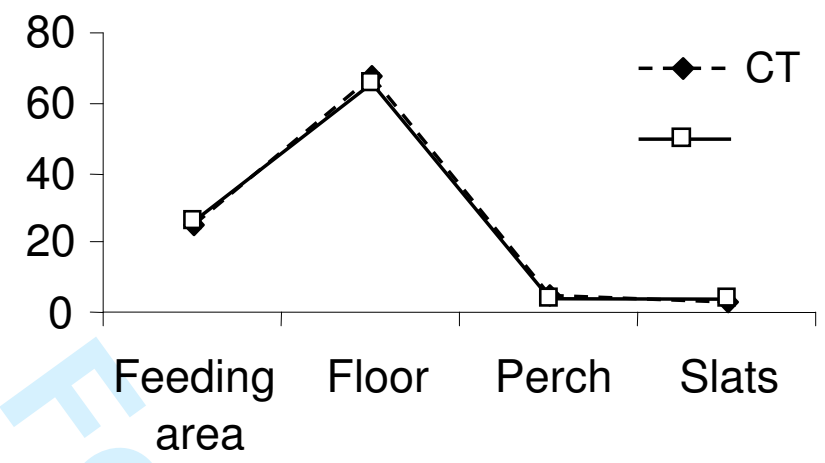

\section{Feather pecking locations}

FIGURE 3. Feather pecking locations of occurrence.

$22 \quad 489$

